\title{
Ethnicity Situation and Intolerant Attitudes in Multicultural Societies in the Medan City
}

\author{
Erond Litno Damanik \\ Universitas Negeri Medan, Indonesia \\ Email: eronddamanik@unimed.ac.id
}

\begin{abstract}
This article aims to explore and discuss the phenomenon of intolerant attitudes in multicultural societies. Empirically, the substance of the study is focused on strengthening discrimination and segregation in Medan City. The fundamental problem is formulated in the question: is it true that intolerant attitudes have an impact on discrimination and segregation in multicultural societies? This study was conducted qualitatively with a descriptive approach. Data collected through in-depth interviews and questionnaires. Theoretically, the reference used is the Least-Liked approach developed by Sullivan. Data analysis refers to eight attribute values tolerant according to Ingelhart. The study's finding is that the Least-Liked attitude is the failure of an assimilationist political mechanism. Multiculturalism is influenced by ethnicity situations that do not guarantee the emergence of multiculturalist attitudes but have the least related effects, discrimination, and segregation. The novelty of this study lies in the idea of multiculturalism which is lacking in the support of assimilative politics. Theoretically, the contribution of this study reinforces Sullivan's assumptions and empirically emphasizes the importance of assimilative political mechanisms in multicultural societies.
\end{abstract}

Keywords: ethnicity situation; intolerant attitudes; multicultural; segregation

\section{INTRODUCTION}

The results of the Setara Institute study in 2018 stated that Medan became one of the intolerant cities in Indonesia (Susanto, 2018). Medan has a Tolerant City Index (Indeks Kota Tolerant, IKT) score of 3,710 and ranks eighth out of 10 intolerant cities in Indonesia. The measurement of IKT scores is based on tolerance practices, namely freedom of religion and belief, gender equality, guaranteed and protected social inclusion, and the statements and actions of government officials. The Setara Institute study is based on government participation to create tolerant cities in Indonesia.

This article intends to measure the tolerant attitudes of multicultural communities in Medan using an anthropological and historical perspective. This perspective will complement multidimensional studies of previous tolerance such as the World Value Survey
(WVS) or the Global Social Tolerance Index (GSTI) (Zanakis, 2016) or the General Social Survey (GSS) (Mather, 2014). This article combines the attributes of democratic values according to GSTI and GSS (Ingelhart, 1997).

Through this article, we offer a new approach to measuring tolerance, namely civil liberties and personal relations. The significance of this article is to look at the social distance that reflects intolerant attitudes in multicultural societies. The intolerant attitude is seen from the dimension of democratic value, namely the base of the choice of mate, interpersonal trust, comfort in social-political institutions; the reason for choosing settlements, employees, schools, and attitude for religious and cultural practices. These eight dimensions represent social distance in a multicultural society according to the 
scope based on religion, ethnicity, economy, and politics Refer to the Setara Institute data that Medan is an intolerant city. This indication is reinforced by the existence of several phenomena that show the existence of intolerant attitudes to social life. In the religious arena, for example, there are prohibitions on the establishment of houses of worship, demolition of houses of worship, prohibitions on religious activities, prohibitions on saying other people's religious celebrations, the use of other religious symbols, restrictions on religious celebrations by the government, including suicide bombings in houses of worship (Padang, 2011).

In the social arena, for example, there is a ban on the sale and rental of houses, land or shops to people of different faiths and ethnicities. The same phenomenon is found in boarding houses for students. Also, there is a sharp increase in segregative settlements according to religion, ethnicity, and the economy. Another thing is the prohibition on non-halal restaurants, intermarriage between religions and ethnicities, employee recruitment and polarization based on ethnic and religious schools and others. Overall this phenomenon indicates their intolerant attitudes.

Tolerance has different definitions according to discipline. However, in general, tolerance refers to the level of acceptance of differences, willingness to give equal rights, and defend themselves from open intolerance. In this article, the notion of tolerance is expressed anthropologically namely "sympathy or pleasure for beliefs or practices that are different or contrary to one's own" (Merriam-Webster Dictionary, 2010)

In a pluralistic society such as Medan City, each ethnic group has a different identity. Identity can be patterned primordial, economic, cultural, social, or political. "Ethnic identity requires the maintenance of sufficiently consistent behavior to enable others to place an individual or group in some given social category, thus permitting appropriate interactive behavior" (De Vos, 1975; Royce, 1982). This reality is the basis for every individual or group to developed, manipulate and ignored according to a particular situation. They identify power, perception, and purpose as the fundamental criteria which determine behavior in any inter-ethnic situation (Hidayat dan Damanik, 2018).

Tolerance is an important concept in peace (Sullivan, 1982). Tolerance contains modern political and social values that are articulated as the basis of social cohesion (Sullivan, 1999; UNESCO, 2004). "Tolerance refers to the level of recognition and acceptance of differences, willingness to give equal rights, and openly refrain from intolerant attitudes" (Zanakis, 2016).
Tolerance is the core of life where every difference in given nature such as race, ethnicity, skin color, religion, culture can coexist. Likewise, differences due to economy, politics, work, assigned education can live side by side.

Tolerance can be observed from signs or behaviors that reflect democratic life, namely: language: absence of racial, ethnic, and gender epithets; public order: characterized by equality among persons; social relations: based on mutual respect for humanity in society; political processes: essentially democratic opportunities for participation of minorities, men and women; majorityminority relations and indigenous people: human dignity and all rights of persons and indigenous people are respected; communal events, historical observation; cultural events and manifestations; religious practices, and intergroup co-operation (UNESCO, 2004). Conversely, intolerance reflects the rejection of other people and groups.

Intolerant attitudes refer to the "Least Liked" feeling towards other people or groups (Sullivan et al. 1982; 1999). Symptoms of intolerance and their attitudes can be observed from indicators such as language namely denial language rights; stereotyping; alienation; prejudice; scapegoating; discrimination; ostracism; harassment; desecration and effacement; bullying; expulsion; exclusion; segregation; repression, and destruction (UNESCO, 2004). In a pluralistic society, assimilation policies are needed to reduce intolerant attitudes (Odland, 1976).

It is important to underline that people in Medan City are a mixture of ethnicities that are explosive according to religion and ethnicity (Geertz, 1975). This explosive ethnic mixture has implications for the existence of ethnic divisions according to their primordial attributes (Damanik, 2019b). The consequences of this situation lead to mutual suspicion or high jealousy. As noted by Bruner, there is no dominant culture in Medan City. This fact has negative implications where each ethnic group has the freedom to develop their own ethnic identity. This situation has an impact on social life that is fragmented. This situation is the reason for the development of intolerant attitudes in a pluralistic society (Bruner, 1961). In the end, this situation brought every ethnic group to live in groups according to its primordial attributes. Also, the lack of government regulation through integration policies, such as mixed settlement policies, has implications for the low acculturation and assimilation. This factor also creates intolerant attitudes towards the community.

In this study, intolerant attitudes are seen from two perspectives namely historical and anthropological. 
The historical perspectives see that intolerance emerges through segregative policies from the colonial era (Pelly, 2013). Whereas, the anthropology perspective sees that intolerant attitudes are an unwillingness to accept plural and multicultural society. This study will examine the dimensions of tolerance values on eight attributes (Ingelhart, 1997). The study involved 250 informants consisting of 125 who lived in settlement complexes and 125 living outside the settlement. The homogeneous residential complexes that are the target of the research are Taman Setia Budi Indah, Taman Malibu Indah, Citra Garden, Cemara Asri, Royal Mansion and Rajawali. The outside of this settlement, the research was conducted in Kesawan, Madras, Perumnas Mandala and Simalingkar, Kota Maksum, and Padang Bulan.

The technique of data collection is done through in-depth interviews and questionnaires that contain dimensions of tolerance value according to Ingelhart. In-depth interviews and questionnaires were conducted on several informants who were inside or outside the settlement. The answers to the questionnaire are calculated based on the Likert scale. Analysis and discussion are carried out in-depth analysis to get the conclusion.

\section{RESULTS AND DISCUSSION}

\section{Ethnicity Situation, Segregation and the Origin of Intolerant Attitudes}

According to Pelly (2013), the ethnicity situation in Medan since 1871 reflects a heterogeneous region, namely race, ethnic and religion. The heterogeneity of the people in this area is beginning from the importation of coolies from outside of North Sumatra. Some European and Asia like China and India and also local migrants such as Javanese, Minangkabau, Aceh, Banjar, Simalungun, Toba, Mandailing, Angkola, Pakpak, and Karo. Malay is an ethnic host in Medan City. Referring to the data recorded by Pelly (2013), the following in Table 1 describes a population comparison of Medan in 1930 and 1980.

Although it is called heterogeneous but does not reflect the existence of a "dominant culture" (Bruner, 1961). The tendency of the people is an "explosive ethnic mixture" (Geertz, 1975). Ethnic divisions have occurred since the colonial era due to ethnic and religious factors (Bruner, 1961; Castles, 2001; Geertz, 1975; Perret, 2010; Reid., 1992). Furthermore, colonialism has an impact on social life such as economic, political, cultural activities including the strata of society. The European occupy the upper class, Chinese and Indian positions in the middle class while the indigenous are in the lower class (Pelly, 2013a).
Table 1. Comparison of ethnic groups in Medan City, 1930 and 1980

\begin{tabular}{|c|c|c|}
\hline \multirow{2}{*}{ Race or ethnic } & \multicolumn{2}{|c|}{ years and total population } \\
\cline { 2 - 3 } & $\mathbf{1 9 3 0}^{*}$ & $\mathbf{1 9 8 0}^{*}$ \\
\cline { 2 - 3 } & $\mathbf{7 6 . 5 8 4}$ & $\mathbf{1 . 2 9 4 . 1 3 2}^{*}$ \\
\hline Javanese & 25.5 & 31.3 \\
\hline Tobanese & 1.1 & 14.1 \\
\hline Chinese & 35.6 & 12.8 \\
\hline Mandailing \& Angkola & 6.4 & 11.9 \\
\hline Minang & 7.3 & 10.9 \\
\hline Malay & 7.1 & 8.6 \\
\hline Karonese & 0.2 & 4.0 \\
\hline Acehnese & 0.5 & 1.9 \\
\hline Simalungun & 0.7 & 1.8 \\
\hline Pakpak & 2.3 & 0.2 \\
\hline Nias & - & 0.2 \\
\hline Others & 14.3 & 3.0 \\
\hline
\end{tabular}

In terms of work, Europeans who are owners of capital to be planters tend to occupy upper until middle management, Indian and Chinese are in lower positions, while indigenous become workers. The settlements are formed segmentally such as Europeanwijk for Europeans in Polonia, Chinesewijk for Chinese in Kesawan, Indianwijk for Indians in Kampung Madras and inlanderwijk for indigenous people in Kota Maksum. Other indigenous people tend to be in plantation villages, such as in Marelan, Saentis, Mabar, Helvetia, Tanjung Morawa, Padang Bulan, Sunggal, Amplas, Denai, and others. The Europeans are grouped as Kawula Europa (citizens of the Governorate), namely, everyone who lives in the Gemeente Medan, works on a plantation or a Dutch company. Indigenous people, namely suburban communities, are grouped as the Kawula Sultan (sultanate citizens).

The trend during the colonial era was the existence of segregation. Different communities in this region cannot be integrated but tend to be separated. This fact does not give birth to a Kuali Pembauran (melting pot), namely the existence of an assimilative society. Each community unit lives together in groups or separates from the others. Finally, each social unit finds it difficult to accept and recognize different individuals or groups. In other words, the embryo of intolerant attitudes today cannot be separated from the colonialism period.

The composition of the demography changed dramatically in the plantation era. Referring to Anderson's notes in 1823 , the population is only 200 people (Anderson, 
1971). However, since the plantation era, there has been a drastic increase. Table 2 below illustrates the population heterogeneity in 1905, 1915, 1920 and 1930.

Table 2. The composition of demography in Medan City

\begin{tabular}{|c|c|c|c|c|}
\hline \multirow{2}{*}{ race or ethnic } & \multicolumn{4}{|c|}{ years } \\
\cline { 2 - 3 } & $\mathbf{1 9 0 5}^{\mathbf{1}}$ & $\mathbf{1 9 1 5}^{\mathbf{2}}$ & $\mathbf{1 9 2 0}^{\mathbf{2}}$ & $\mathbf{1 9 3 0}^{\mathbf{3}}$ \\
\hline European & 954 & 1.408 & 3.128 & 4.292 \\
\hline Chinese & 6.397 & 10.997 & \multirow{2}{*}{18.297} & 27.180 \\
\hline Arabs, Indians & 3.708 & 1.318 & & 3.408 \\
\hline Indigenous & 2.191 & 13.257 & 23.823 & 40.096 \\
\hline Total & 13.250 & 26.980 & 45.248 & 76.584 \\
\hline
\end{tabular}

Source: ${ }^{1}$ (Handelsvereniging, 1912); ${ }^{2}$ (Milone, 1964); and ${ }^{3}$ (Pelly, 2013)

The heterogeneity of the population in the colonial era changed the situation of ethnicity, namely the existence of segregation. Ethnicity has a powerful and influential economic motive and urban spatial planning. Every ethnic domination always has an impact on spatial. The city grew bigger offset by the increasing number of ethnic groups. Cluster patterns increasingly shift to ethnic and spatial heterogeneity and show increasingly sharp settlement groupings (Prabowo, 2005).

The cities in the colonial era were divided into three classes namely Europe, China and Indigenous (Nas, 1997). The development of the Chinese population trade sector that developed in the early $19^{\text {th }}$ century triggered a segregation policy (Nas, 1997; Reid., 1979; Sinulingga, 1976). The main objective of this policy is to control the economy of the Chinese. Based on its ethnicity, the population in the Medan in 2000 consisted of Javanese, Toba, Chinese, Mandailing, Minangkabau, Melayu, Karo, Aceh, Sundanese, Simalungun, Pakpak, Nias, Banjar, and others. Based on religion, the demographics in Medan are: Islam (67.83\%), Catholicism (2.89\%), Protestantism (18.13\%), Buddhism (10.4\%), Hinduism (0.68\%), others $(0.07 \%)$. In 2015, the population of Medan was 2,036,018. Based on the Indonesian Population Census in 2010, the population of Medan is 2,109,339 (BPS, 2016).

The data above refers to the fact heterogeneity of the population in Medan and the reason is called a miniature of Indonesia. However, Medan is still at the stage towards a multicultural society and has not fully reflected multiculturalism. This fact is evidenced by the attitudes of intolerance in society such as segregation.

Segregation is an intolerant form in the inequality that is formed because of isolation. The segregation reflects the enforced separation of groups in a homogeneous community (Damanik, 2019a). Settlement segregation, for example, reflects a spatial concentration based on race, ethnicity, religion, and economics (Audi, 2011). Segregation is the practice of intentional isolation that is formed through choices in society (Lynch, 2006).

The segregation is formed because (i) individual preferences to join primordial ties in the form of race, ethnicity, religion, and (ii) economy (Bruch, 2006). Besides, segregation also occurs in aspects of education and employment (Kramer, 2009) as well as politics (Hale, 2004). Segregation exacerbates social class inequality (Lehr, 2011), exacerbates poverty (Anderson, 2011) and impacts on increasing intolerant attitudes.

The segregative settlements in Bali occur because of the influence of immigrant and native populations (Paturusi, 2016). In Ambon, segregation occurs because of the influence of religion namely Islam and Christianity (Sigit, 2015). The modernization of the city can occur because the process is planned or not planned and has an impact on the development of the region (Setyohadi, 2007). The regional development has an impact on zoning in cities. In this case, settlements become one of the spaces that must be arranged so that various ethnic groups can interact or socialize (Sukanti, 1979). The pattern of settlements blends or places public space, the government office at the boundary of segregative settlements is a solution to the reduction of intolerance.

The factors of modernization are certainly driving urbanization (Rappoport,1977; Sukanti, 1979; Tjiptoherianto, 1999). Urbanization requires relatively large settlements for urbanites. In Medan, settlement needs through the emergence of apartments in the urban core. In the urban core, there is a buildup of the population, economic activity, wild and slum settlements (Basundoro, 2005). Urban planners failed to design expansion outside the urban core to break down the density (Setyohadi, 2007). The grouping of ethnic-based settlements in Medan affects the structure of urban space, namely the density, function, and shape of urban space (Jessica, 2012).

The segregation of settlements in Lombok occurs because of the social stratification (Mustain, 2013). In the Oi Bura, Tambora, segregation of settlements was carried out based on ethnicity and religion (Hidayat, 2018). In Japan, for example, spatial boundaries are interpreted in the outside-classification which forms not only physical and home borders but also reinforces psychological boundaries in human relationships (Ozaki, 2004).

The absence of spatial arrangements that reduce segregation has an impact on strengthening social 
boundaries. This condition is very likely to close interaction and social relations. Non-existent communication closes the space of tolerance. The intended space arrangement is a policy of removing social boundaries in each component of social life. Borderless policies like the placement of public spaces between different classes, assimilative schools, and the establishment of government offices between segregative areas.

The basic boundaries of social classifications which regulate human behavior and boundaries are useful when considering the meaning and cultural variation of spatial settlement. The effect of spatial arrangements depends on species identity but is also strongly contextdependent. There are large-scale competitive abilities, aggregated spatial arrangements can be slow competitive exclusion, and non-random spatial arrangements can work synergistically with other trade-off mechanisms to facilitate coexistence (Hart, 2009). It can be concluded that the ethnicity situation does not accommodate differences has an impact on the existence of segregation. On the one hand, this condition is a factor in the emergence of intolerant attitudes as outlined below.

\section{Eight Attributes of Intolerant Attitudes}

The first dimension of intolerant attitudes is ethnocentrism on neighboring attributes. The attribute value of tolerance shows that the majority of informants want their neighbors to come from the same identity. The most expected similarity of identity is homogeneous religion and ethnicity. This situation is a sign of ethnocentrism in society. This fact shows that neighbors of different religions and ethnicities are still less favored. Therefore, it is understandable if the trend that occurs in the city of Medan is the presence of settlements based on religion and ethnicity. Another reality in this neighboring aspect is the tendency of rental houses, boarding houses, and lands or house sales in homogeneous groups. Ironically, none of the informants wanted the existence of a blending neighbor, namely the community who did not question the background of their neighbors.

This fact strongly supports the initial assumption that intolerant attitudes emerge in the form of segregation of settlements. The question like 'what ethnic is he?' or 'what religion is he?' is often the basis of social interaction. This fact indicates a restriction of social interaction in the form of least-like differences in multicultural societies. Historical facts indicate the existence of ethnic and political opposition Muhammadyah (Muthi, 1957) fellow Minangkabau nomads, Al Djamiatul Alwasliyah (Endicott., 1970), social revolution namely ethnic revenge (Reid., 1979; Said, 1973), Negara Sumatra Timur
(Langenberg, 1977), anti-Chinese (Mackie, 1976), Poh An Tui (Veer, 2013) or the 1998 riots that hit the Chinese in Medan, the Batak label conflict in the Mandailing and Angkola ethnic groups (Pelly, 2013a) or opposition at the top of the military between Toba, Karo, and Java in the PRRI/Permesta era (Small, 1968).

Figure 1 below is a dimension of ethnocentrism in the attributes of couple selection. Although not absolute, the majority of informants chose a couple based on religious and ethnic. Meanwhile, some informants stated that work or economics was the basis for choosing a couple and the similarity of the class as the basis for choosing a mate.

Figure 1. Reason for choosing a mate

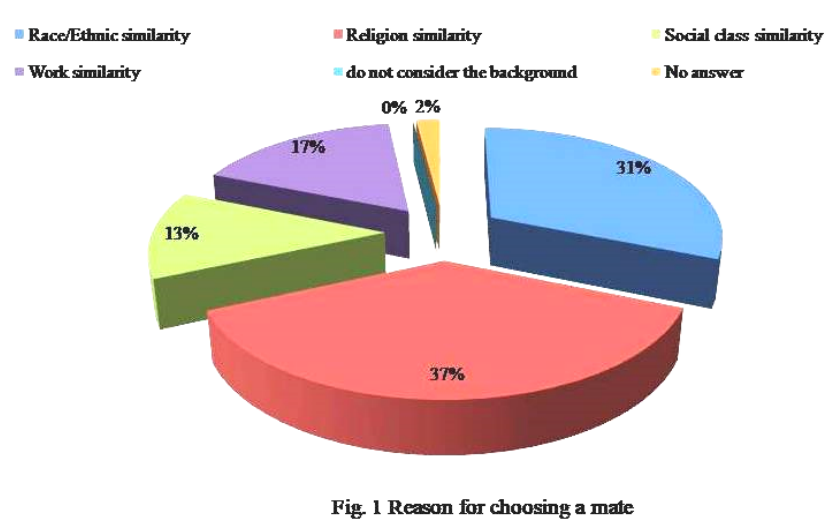

The data in Figure 1 above illustrates that intermarriage between religions is still difficult. Regulatory, interfaith marriages are not permitted in Indonesia. Therefore, couples of different religions are required to choose one religion when married. Meanwhile, the basis of consideration in racial or ethnic similarity generally occurs in Chinese people. Race or ethnic purity is very guarded, especially limiting the transmission of entrepreneurial genes to non-Chinese people.

Meanwhile, there are restrictions on marriage between ethnic or racial groups such as between Toba and Karo or Mandailing. Although both couples have the same religion, ethnicity is a consideration, especially regarding ways of thinking, working or stereotyping inherent in certain ethnic groups. All of these phenomena become intolerant attitudes, namely the absence of differences in the determination of couples in a multicultural society. Every human being always chooses somebody who is his group or their mate that comes from specific considerations. In general, the basis of the selection came from racial, ethnic and religious similarities (Smith, 1981). In other words, interfaith and ethnic marriage is 
not expected and has become a barrier to tolerance in multicultural communities.

The next dimension of tolerance is social communication on the attributes of interpersonal trust. This attribute aims to see the degree of individual trust with others and the factors that underlie the intended trust. The majority of informants stated that they put their trust in others who had the same religion and ethnicity. The social implication is the lack of trust with others Ironically, mistrust also permeates every professional organization, educational and social institution and others. Friendship tends to bind fellow members of the same attributes as ethnic and religious. Likewise in the aspect of choosing a couple of neighbors prefer homogeneous groups rather than heterogeneous.

Based on data from the subject, information was obtained about the inter-personal trust crisis. This fact is a response to suspicion of growing mutual trust. Every social activity is always suspected of having a negative charge. The business patrons and networks tend to come from homogeneous groups. Ironically, the similarity of religion and ethnicity often criminals, radical movements or terrorists are mushrooming. A permissive attitude towards others due to identity similarity has increased in Indonesia, including in North Sumatra. Social reality as seen by the final result of the suicide bombers. Some people mention 'unexpected', 'good behavior', 'frequent worship' and others. Ironically, suicide bombers and radical movements come from religious institutions (Benmelech, 2007; Brym, 2007). This situation is the basis that intolerant attitudes are born from the distrust of others.

The next dimension of tolerance value is the attribute of comfort in socio-political institutions. The majority of informants responded that religion and the religious association were the most comfortable. These institutions provide comfort because they can stay in touch, socialize, share and feel each other. This kind of social life can be seen from the tendency of social gathering, association or social activities with a sense of religious life. Meanwhile, political parties and education are social institutions that are considered uncomfortable. This situation has implications for the political behavior of citizens who tend to local executives election.

In Medan, anti-Chinese occurs in the political sector, especially among Muslim Santri and their allies (Mackie, 1976). Organizations such as Pemuda Pancasila, PP (Pancasila Youth) namely IPKI affiliation and later Golkar are very anti-Chinese (Pelly, 2013a). The Anti-Chinese Movement in Medan seeped in every riot in the form of looting carried out by becak drivers, street vendors, and ordinary people. The AntiChinese Movement increased because of economic competition (Skinner., 1963; Wertheim., 1965). Likewise, Minangkabau people have anti-Chinese feelings because of economic competition (Feith, 1963). However, some Chinese elites have obtained positions in the Pemuda Pancasila today. In this way, the Anti-Chinese movement is expected to be reduced.

The education should be an entrance to tolerance, namely a place to teach equality. However, even this institution is not believed to foster tolerance so that the people who come out of this institution give birth to a generation of intolerance. The school's segregation is very different in contrast to each social strata. At school, every student does not get friends from various backgrounds but tends to come from a homogeneous ethnic and religious background.

Intolerant attitudes seep into the political arena such as determining local legislative and executive elections. In the political arena, intolerant attitudes have occurred since the Presidential Election in 2014. Intolerant attitudes strengthened in the Jakarta Election in 2017. Although the local election was conducted in Jakarta, from Sabang to Merauke observed it through social media and television. According to data at the Setara Institute 2018, the intolerant attitudes have increased sharply in Jakarta in the form of primordial ties (Susanto, 2018).

In Medan, the butterfly effect of the Jakarta Election was felt in religious and ethnic politics. The people of Medan are polarized on two candidates according to primordial ties. This fact made the ethnicity situation heat up. Intolerant attitudes strengthen by rejecting differences. Previously, in 2010, Sofyan Tan became a candidate for the mayor of Medan. The Chinese, Aseng, Kafir and other expressions rose sharply which was intended to reject Sofyan Tan.

The increased of intolerant attitudes was allegedly affected by economic and political inequalities or the failure of multicultural education. Economic level differences namely mastery of the production sectors widen the social strata between the upper-middle and lower class. At the top position, there are Chinese. They are capital owners who master the export and import lines, dialers, showrooms, distributors, sole and small agents. Chinese control almost all economic activities in Medan ranging from real estate, hotels, banks, superblocks, hospitals, shops, educational institutions, industry, advertising, plantation, manufacturing and even culinary.

Even if there are non-Chinese ethnic groups in institutions, companies, shops controlled by China, 
their position is only at the middle management level. This fact led to social jealousy which gave birth to an intolerant attitude. On the contrary, the Toba, Mandailing, Simalungun, Malay, and Javanese tend to fill the government bureaucracy. They work as a government office, teacher, medical administration and technocrat. In the political arena, the entire component of society spread to nationalist, religious and nationalist-religious.

In the arena of religiosity, intolerant attitudes are evident from the refusal of the construction of houses of worship. Also the refusal of the use of religious attributes at certain celebrations and the prohibition of the pronunciation of typical religious greetings. The bomb explosions in houses of worship or the collapse of houses of worship are part of intolerant behavior. Another phenomenon can be seen from the refusal of non-halal restaurants, worship activities at home, and also activities by the different religions. Another case in the intolerant attitudes including views on traditional religion and certain religious sects which tend to be negative (Padang, 2011).

The data in Figure 2 below shows the dimension of tolerance in the attribute of choosing a residence. The majority of informants gave answers that religion was the main consideration in determining settlements. Not surprisingly, several settlements are originating from homogeneous or primordial ties.

Figure 2. Attributes of residence selection

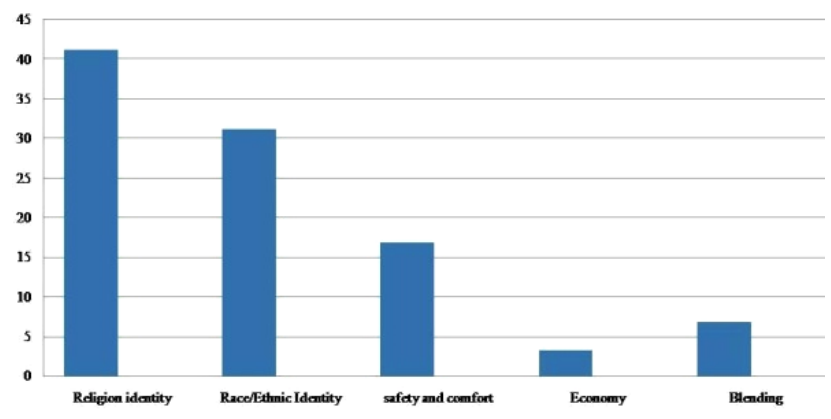

Meanwhile, relatively few informants who chose settlements blended as a basis for consideration. Besides that, some informants make security and comfort as the basis for consideration of determining settlements. Indirectly, housing prices are very useful in determining social class. The Chinese controlled the Indonesian economy and the highest layers of the Indonesian economic system (Mackie, 1976). The Chinese are clustered in the urban core and surrounding areas such as Medan Kota, Medan Baru, Medan Barat, and Medan Timur sub-districts. The Minangkabau do not build shops like China but tend to rent in trading locations. Minangkabau cluster around the central market at Sambu (Pelly, 2013a). Mandailing, Angkola and Malay people cluster in the Sungai Mati, Kampung Masjid, Glugur, and Kota Maksum. These are a former plantation and colonial bureaucrats, and until today, especially Mandailing tend to master the ranks of government.

The Javanese work in the informal sector which is uneducated. The group is the proletariat in Medan (Langenberg, 1977). The Javanese are mostly descendants of the colonial era as contract coolies (Said, 1977). Javanese cluster around Helvetia, Johor, Sunggal, Marelan, and Tembung. The largest migrants like Tobanese are included in Medan (Cunningham, 1958). They are land hunters, occupying government positions and tend to be educated. Toba cluster in Medan Timur, Medan Denai, Medan Sunggal, and Medan Johor. Karonese cluster in Padang Bulan, Medan Baru, Tuntungan, Titi Rantei, Babura, and Simalingkar.

In the residential, intolerant attitudes are seen in the segregative settlements. The segregative settlements resemble villages in the middle of the city that refer to their respective identities. The Chinese are in Kesawan and Medan Area, Indian in Kampung Madras, Arab and Minangkabau Kota Maksum, Karo in Padang Bulan, Toba in Southeast and East Medan, Mandailing and Angkola in Tembung, Javanese around Helvetia, Martubung and Marelan, Simalungun and Nias around Teladan, Acehnese around Gajah Mada, Banjar and Minahasa around Helvetia, and Malays around Maimoon, Labuhandeli and Pulau Brayan.

The intolerant attitudes are seen in the selection of settlements based on socio-economic strata. Table 3 below shows the trends in the choice of residence in Medan.

Table 3. Dimension of residence consideration

\begin{tabular}{|c|c|c|}
\hline \multirow{2}{*}{ Attributes of democratic values } & \multicolumn{2}{|c|}{ Tendency of answers } \\
\cline { 2 - 3 } & amount & $\mathbf{\%}$ \\
\hline Religion/belief & 103 & 41,2 \\
\hline Race/ethnic & 78 & 31,2 \\
\hline Safety or comfort & 42 & 16,8 \\
\hline Economy & 8 & 3,2 \\
\hline Assimilation or mixture & 17 & 6,8 \\
\hline No answers & 2 & 0,8 \\
\hline Total (n) & 250 & 100 \\
\hline
\end{tabular}


The Setia Budi, Malibu Indah, Citra Garden, Citra Bagyaland, Cemara Asri, Royal Mansion in Marelan, Tanjung Rejo, Rajawali in Medan Sunggal, and others are examples of exclusive settlements for the upper class. These settlements in the form of agglomeration tend to be dominated by China and some local elites in Medan. The settlements for the middle class are Menteng Indah. The growth of settlements for this class is very high, a sign of the rise of the middle class in this city. The settlements like this tend to have a wall and security unit. Meanwhile, lower-class settlements are Perumnas or Sejuta Rumah, the national PUPR program (2014-2024). Although this problem can be called a natural thing that is related to security and economy, it also supports the emergence of intolerant behavior.

Intolerant attitudes also occur inland and home sales, and rental housing. Many cases in Medan that houses and land are only sold or rented to homogeneous groups based on religion and ethnic. Some housing entrepreneurs only offer houses in homogeneous groups. Even boarding houses and dormitories are only intended for homogeneous groups. It is not strange if there is a pamphlet that writes 'only for a certain amount' which refers to homogenous groups. The choice of shopping is characterized by an elitist, semi-elitist and not elitist mall. The lower classes shop in the center of markets or malls that are by their economic capabilities. The social class can recognize the brand of car that is parked in the plaza. Typically, every individual or community has the freedom of shopping. However, the segregation of shopping is creating a class gap based on the economy which triggers intolerant attitudes.

The next dimension of tolerance value is the attribute of employee recruitment. The majority of informants stated academic ability and professionalism as the basis for determining employees. However, some informants stated primordial ties as the basis for determining employees. Each entrepreneur, like the Chinese, prefers employees based on professionalism and interfaith. The assumption is to avoid certain religious celebration holidays. With the presence of employees from across religions, workers can take turns off so that the business continues to run well. However, some informants state that workers from homogeneous groups are needed to guarantee business success such as culinary. The data shows the existence of intolerant attitudes in choosing employee's consideration. Not a few employees choose jobs because of their primordial suitability. These realities arise because of the segregation that occurs in society. The employees can foster tolerant attitudes by accepting workers from different social crossings. At work, each person with a different background can learn to accept differences in their respective attributes.

In the economic arena, intolerant attitudes can be seen from the structure of management, the rejection of facilities such as shops, warehouses or malls. The Chinese community controls every economic factor from exports and imports to large, small, and small-scale companies. Minangkabau controls the restaurant sector and hawkers. Indians tend to sports shops. The Toba, Simalungun, Arab, Banjar, Malay, Karonese, Pakpak, Nias, Acehnese, and others controlled the informal sector. However, most of their economic endeavors are employs to Chinese people. This phenomenon raises hatred towards Chinese people which is manifested through intolerant attitudes.

The next dimension of tolerance value is the attribute of school selection. In the city of Medan, the schools can be identified as public schools, private national and private religions. Public schools are government schools, namely national school. National private schools are schools managed by the private sector but are nationally-oriented. While private religious schools are schools affiliated with certain religions. For example, Christian schools such as Methodists, Catholics, Protestants, Adventists, Buddhist schools, Hindu schools, Islamic schools are based on Nahdatul Ulama, Muhammadiyah and Al-Wasliyah. However, some schools claim to be mixed schools. Although the school is a primary need for the community, the segregative schools can emerge as a factor in intolerant attitudes.

The majority of informants chose public schools. However, the choices for religious schools are also high. The consideration of schools is an important means of growing tolerance. Everyone who has a different background will be relatively easy to accept differences. Conversely, in inhomogeneous schools, it will be relatively difficult to accept differences. In Medan, religious schools such as Methodists and Catholics tend to be the target of both Chinese and Christian elites. This school has a reputation that is superior to public schools. Likewise, there are a small number of Christians who choose Islamic schools as a place to receive knowledge.

However, very rarely do Muslims adhere to Christian education. Although education is the main need, education also gives birth to intolerant attitudes and behaviors in the form of grouping on homogeneous identities. The data about school selection is illustrated that education segmentation is very real. The popular schools, especially private schools, are the upper-class targets, while the middle and lower classes target public 
schools. Another problem that is often a source of criticism in society is the failure of education to foster intolerant attitudes.

The last dimension of tolerance value is the attribute of informant attitudes about religious, cultural and ethnic practices in a multicultural society. Based on the informant's answer, it strongly disagrees with different religious, ethnic and cultural activities. The data in Table 4 below shows the tendency of the informants' answers to the practice of religion and ethnic culture.

Table 4. Attributes of religious and cultural practices

\begin{tabular}{|c|c|c|}
\hline \multirow{2}{*}{$\begin{array}{c}\text { Attributes of democratic } \\
\text { values }\end{array}$} & \multicolumn{2}{|c|}{ tendency of answers } \\
\cline { 2 - 3 } & amount & $\mathbf{\%}$ \\
\hline strongly agree & 76 & 30,4 \\
\hline agree & 38 & 15,2 \\
\hline less agree & 42 & 16,8 \\
\hline strongly disagree & 88 & 35,2 \\
\hline no answer & 6 & 2,4 \\
\hline total (n) & 250 & 100 \\
\hline
\end{tabular}

The data in Table 4 above shows that there is disagreement in the practice of religious and other ethnic cultures. Therefore, religious, ethnic and cultural activities cannot be avoided by society. Rejection of activities like this is a clue that looks at intolerant behavior in a multicultural society. Activities such as the Islamic Festival, Christmas Season, Imlek Fair, Devavali Fair, and others tend to be attended by homogeneous groups. Ethnic groups tend to be divided because of religion. This tendency tends to negate life as a social citizen. This refusal behavior appears in the reluctance to attend different religious and cultural activities.

Furthermore, the existence of stereotypes in society is seen as part of intolerant attitudes like Pemalas (lazy for Malays), Pungo (stupid for Acehnese), mancilok (for Minangkabau), manipol (for Mandailing), gerobak Pasir (for Toba), Keling (for Indians), Aseng (for Chinese), kafir or infidels (for non-Muslims), Bataks (for Mandailing, Angkola, Karo, Pakpak, Simalungun, and Toba) and others.

The description above shows eight attributes of the value of tolerance for plural societies. These data indicate that 250 informants in Medan reflect intolerant attitudes. These attitudes inhibit integration and social cohesion. This reality is seen from mutual suspicion, mutual distrust, or a tendency to feel comfortable in a homogeneous group. According to Geertz, the explosive mixture can explode at any time if the negation of the difference becomes sharper. Not only in Medan, but tolerance in Western and Eastern Europe is also divided because of the effect of religiosity. Tolerant behavior is stronger in secular countries in Western Europe than in Eastern Europe (Vermeer, 2012).

Intolerance is an individual who has symbolic value towards a small number of social attributes and disrespect for others. While tolerant are individuals who have different symbolic values and respect for others (Corneo, 2009). Tolerance is a rational choice to avoid conflicts with heterogeneous societies. Tolerance refers to a personal approach namely the practice of political or philosophical institutions to reduce conflict. Anything that has a deviation with a person or group, a relationship between stances and practices of alienation and provocation (Habermas, 2008). Therefore, the purpose of tolerance is to avoid conflict or something that seems different between views or practices rejecting someone or accepting others in coexistence.

Tolerance is considered to be a sign of maturity and the intolerant is easily regarded as repressive and unimaginative. At the same time, tolerance means accepting that which is conflict-laden and provocative. To be able to be tolerant without exposing yourself to the conflict-laden other, and thus to neither risk being changed nor being repressive, it is appealing to separate oneself from those one beliefs are not worth talking. Although refusing to recognize the other is occasionally regarded as courageous or clear-sighted, it means that the other remains an enemy and that the conversation as an opportunity for change is lost. The fact that people join together in organizations is necessary to make their voices heard and form a joint identity (Essen, 2017; Issacharoff, 2009).

Public spaces are where people and different social groups participate. They provide an opportunity for sharing thoughts and information due to social nets formation (Hajer, 2001). The result of these interactions and experiences among people will be communal identification, self-esteem, public skill improvement, and social participation. This interpretation of public spaces about the social bubbles of people is considered by urban designers (Car, 1992; Douglas, 2003). Public space is a factor for sociability, physical and activity aspects of public spaces, the process of sociability and community improvement (Gehl, 2004; Rad, 2013). The physical quality of public spaces is the first factor to activate these spaces socially due to gathering people and then keeping them in the space. Although factors such as access, "visual attraction, natural elements, and many 
others are significant, the creation of social events is more important than physical features in social presence and interaction since it can provide participation opportunities in social activities and improve the sense of belonging to the place" (Lennard, 1984).

Therefore, policies to reduce intolerant attitudes must be created immediately. In this case, the government has main controls such as the creation of schools, public spaces, markets, hospitals, government facilities, city parks in the boundary area. The primordial differences are a necessity, so tolerant behavior is needed to ensure social sustainability. The whole intolerant phenomenon above exacerbates human rights and peace in society. If this intolerant behavior does not get problem-solving, it certainly has implications for social coexistence.

A multicultural society needs tolerance to ensure the background of its people. The acceptance and recognition of differences are at the core of the principle of tolerance. In other words, the higher the degree of tolerance, the more tolerant the community is intended. This reality is a prerequisite for a peaceful social life. The social reality in the form of intolerant attitudes in the 8 dimensions of democratic value in the Medan reinforces the Least-Liked theory according to Sullivan. The novelty of this study lies in the idea of multiculturalism which is lacking in the support of assimilative politics.

\section{CONCLUSION}

The findings of this study are multiculturalism is influenced by ethnicity situations that do not guarantee the emergence of multiculturalist attitudes but have the least related effects, discrimination, and segregation. Medan is very relevant to be called a multicultural city and become a miniature of Indonesia. However, the ethnicity situation has not yet arrived at the multiculturalist society. The multicultural situation of ethnicity does not guarantee the creation of a multiculturalist order but has the Least-Liked the effect, namely the existence of intolerant attitudes.

The social reality measured by the 8 dimensions of democratic values shows the existence of intolerant attitudes according to Ingelhart. This finding reinforces the basis of the theory used which is Least-Liked as explained by Sullivan. The Least-Liked attitude is the failure of an assimilationist political mechanism. This study concludes three important things. First, Least-Liked is the realization of intolerant attitudes that point to the failure of political and social processes in multicultural societies that trigger dislike for others. Second LeastLiked manifestations are seen in the racial, ethnic and religious-based segregation and third Least-Liked has an impact on the low level of social cohesion which has implications for low interpersonal trust, residential and school segregation, land and house sales, and rental of houses and shops. Tolerance must be a necessity of life to create peace. A multicultural society requires tolerance to guarantee of social life. Only through tolerant behavior is the acceptance and recognition of differences; social coexistence can be achieved.

The policies to reduce intolerant attitudes, experience from Medan City, can be created such as first the creation of mixed settlement patterns, second the creation of patterns of mixed schools, third the creation of public space and government offices in the boundary zone, fourth creating a school curriculum in the form of tolerance education and multiculturalism, and fifth voicing tolerance from the pulpits of religion, education, political parties and social communities in the community.

These five points are important recommendations for fostering tolerance in a plural society. In essence, tolerance requires assimilative politics and policies in every arena of social life. This policy requires regulations and social arrangements that prioritize the development of tolerant attitudes. Finally, the theoretical contribution of this study is to strengthen Sullivan's assumptions and empirically emphasize the importance of assimilative political mechanisms in multicultural societies.

\section{REFERENCES}

Anderson, J. (1971). Mission to East coast of Sumatra in 1823. Kuala Lumpur: Oxford University Press in Asia.

Anderson, K. F. (2011). Racial Residential Segregation and Access to Health Care Coverage: A Multilevel Analysis. Oklahoma State University.

Audi, R. (2011). Democratic Authority and the Separation of Church and State. Oxford: Oxford University Press.

Basundoro, P. (2005). Problem Pemukiman Pasca Revolusi Kemerdekaan: Studi tentang Pemukiman Liar di Kota Surabaya, 1945-1960", dalam Kota Lama Kota Baru: Sejarah Kota-kota di Indonesia sebelum dan sesudah Kemerdekaan. F. Colombijn (ed.), Yogayakarta: Ombak.

Benmelech, E. (2007). Human Capital and the Productivity ofSuicide Bombers. Journal of Economic Perspectives, 21(3), 223-238.

BPS. (2001). Medan Dalam Angka Tahun 2000. Medan: Biro Pusat Statistik Kota Medan.

Bruch, E. E. (2006). Ethnic and Economic Factors in Segregation Process. The University of California.

Bruner, E. M. (1961). Urbanization and Ethnic Identity in North Sumatera. American Anthropologist, LXIII, 
$508-521$.

Brym, R. J. (2007). Six Lessons of Suicide Bombers. Sage Journals, 6(4), 40-45.

Car, S. (1992). Public Space. Massachusetts: Cambridge university press.

Castles, L. (2001). Kehidupan Politik Suatu Karasidenan di Sumatera: Tapanuli 1915-1940. Jakarta: Gramedia Pustaka utama.

Corneo, G. (2009). A Theory of Tolerance. Department of Economics. Berlin: Frie Universiteit.

Cunningham, C. E. (1958). The Postwar Migration of Toba Batak to East Sumatra. New Haven: Yale University Southeast Asia Studies.

Damanik, E. L. (2019a). Ethnic Cleavages: the Descendant and Clan Sentiment on Local Executive Election in North Tapanuli, North Sumatera Province. Komunitas: International Journal of Indonesian Society and Culture, 11(1), 61-76.

Damanik, E. L. (2019b). Gugung dan Jehe: Pembelahan Etnik Karo di Sumatra Utara. Handep: Jurnal Sejarah Dan Budaya, 3(1), 1-32. https://doi.org/ DOI: $10.33652 /$ handep.v3i1.46

Damanik, E. L. \& Hidayat. (2018). Batak dan Bukan Batak: Paradigma Sosiohistoris Tentang Konstruksi Identitas Etnik Di Kota Medan, 1906-1939. Jurnal Sejarah Citra Lekha, 3(2), 71-87.

De Vos, G. A. (1975). Ethnic Identity: Cultural Continuities and Change. Mayfield: Mayfield Publishing Company.

Douglas, M. (2003). Urban Space in the Globalization Era. The Danish Architectural Press.

Endicott., K. M. (1970). An Analysis of Malay Magic. Oxford: Clarendon Press.

Essen, J. von. (2017). What are we doing with Tolerance? In E. Lundberg (Ed.), Mechanisms of tolerance: an anthology. Stockholm: The Living History Forum.

Feith, H. (1963). The Political Dynamics of Guided Democracy. In R. McVey (Ed.), Indonesia. New Haven: Yale University Southeast Asia Studies.

Geertz, C. (1975). The expression of ethnicity in Indonesia. In A. Cohen (Ed.), Urban Ethnicity (ASA Monogr). London: Tavistock.

Gehl, J. (2004). Public Spaces, Public Life. The Danish Architectural Press.

Habermas, J. (2008). Religious Tolerance as Pacemaker for Cultural Rights. In J. Habermas (Ed.), Between Naturalism and Religion: Philosophical Essays. Cambridge, UK: Polity Press.

Hajer, M. (2001). In Search of New Public Domain. Rotterdam: NAI Publishers.

Hale, H. E. (2004). Explaining ethnicity. Comparative Political Studies, 37(4), 458-485.

Handelsvereniging. (1912). Verslag Handelsvereeniging Medan, 1912. Leiden.
Hart, S. P. (2009). Spatial arrangement affects population dynamics and competition independent of community composition. Ecology, 90(6), 1485-1491.

Hidayat. (2018). Segregasi Residensial dan Intersubyektifitas Kewarganegaraan Masyarakat di Desa Oi Bura, Kecamatan Tambora, Kabupaten Bima. Journal of Governance, 3(1), 80-100.

Ingelhart, R. (1997). Modernization and postmodernization: cultural, economic, and political change in 43 societies. Princeton, NJ: Princeton University Press.

Issacharoff, S. (2009). The Public Value of Settlement. Fordham Law Review, 78(3), 1177-1202.

Jessica. (2012). Pengaruh Pengelompokan Permukiman Etnik Terhadap Struktur Ruang Kota Medan. Universitas Indonesia.

Kramer, M. R. (2009). Race, Place, and Scale: Residential Segregation and Racial Disparities in Very Preterm Birth. Emory University.

Langenberg, M. Van. (1977). North Sumatra under the Dutch Colonial Rule: Aspects of Structural Change. Review of Indonesian and Malaysian Affairs, $2(1 \& 2)$.

Lehr, L. S. (2011). Housing Policy and Socio-economic Residential Segregation: The case of Buenos Aires. Georgetown University.

Lennard, G. (1984). Public life in urban places. Southampton: Godlier.

Lynch,A. M.(2006). Do Whites Defend Their Neighborhoods? The Role of Hate Crime in Perpetuating Racial Segregation. George Washington University.

Mackie, J. (1976). Anti-Chinese Out-Breaks in Indonesia, 1959-1968. In J. Mackie (Ed.), The Chinese in Indonesia. Honolulu: The University Press of Hawaii.

Mather, D. M. (2014). New Dimensions of Tolerance: A Case for a Broader Categorical Approach. Sociological Science, 1, 512-531. https://doi.org/DOI:10.15195/ v1.a28

Merriam-Webster Dictionary. (2010). Tolerance.

Milone, P. D. (1964). Contemporary Migration in Indonesia. Asian Survey, 4(8), 1000-1012.

Mustain. (2013). Segregasi Etno-Religius: Upaya Resolusi Konflik dan Pembangunan Perdamaian. Walisongo, 21(1), 71-88.

Muthi, A. (1957). Tigapuluh Tahun Muhammadiyah daerah Sumatra Timur. Medan: Panitia 30 Tahun Muhammadiyah.

Nas, P. J. M. (1997). Colonial City. Leiden: University of Leiden.

Odland, J. (1976). The Spatial Arrangement of Urban Activities: A Simultaneous Location Model. Environment and Planning: Economy and Space, 8(7), 779-791. https://doi.org/10.1068/a080779

Ozaki, R. (2004). Boundaries and the meaning of social space: a study of Japanese house plans. Environment and Planning Development Society and Space., 24, 
91-104.

Padang, F. W. (2011). Potret Kehidupan Beragama/ Berkeyakinan di Sumatera Utara: Laporan Pemantauan Aliansi Sumut Bersatu Tahun 2011. Medan.

Paturusi, S. A. (2016). Segregasi Ruang Sosial Antara Pendatang dengan Penduduk Asli pada Permukiman Perkotaan di Denpasar. Jurnal Kajian Bali., 6(2), 5778.

Pelly, U. (2013a). Urbanisasi dan Adaptasi: Peranan Misi Budaya Mandailing dan Minangkabau di Kota Medan. Medan: Unimed Press dan Casa Mesra.

Pelly, U. (2013b). Urbanisasi dan Adaptasi: Peranan Misi Budaya Minangkabau dan Mandailing di Kota Medan. Medan: Unimed Press dan Casa Mesra.

Perret, D. (2010). Kolonialisme dan Etnisitas: Batak dan Melayu di Sumatra Timurlaut. Jakarta: Kepustakaan Popular Gramedia dan EFEO-Jakarta.

Prabowo, H. (2005). Masalah Etnisitas dan Tata Ruang di Indonesia. In Nasional PESAT. Jakarta: Universitas Guna Dharma.

Rad, V. B. (2013). The Role of Public Spaces in Promoting Social Interactions. International Journal of Current Engineering and Technology, 3(1), 184-188.

Rappoport., A. (1977). Human Aspects of Urban Form. Oxford: Pergamon Press.

Reid., A. (1979). The Blood of the People: Revolution and the End of Traditional Rule in Northern Sumatera. Kuala Lumpur: Oxford University Press in Asia.

Reid., A. (1992). Perjuangan Rakyat: Revolusi dan Hancurnya Kerajaan Tradisional di Sumatra. Jakarta: Sinar Harapan.

Royce, A. P. (1982). Ethnic Identity: Strategies of Diversity. Bloomington: Indiana University Press.

Said, M. (1973). What was the 'Social Revolution' of 1946 in East Sumatra? Indonesia (Vol. 15).

Said, M. (1977). Koeli Kontrak Tempoe Doeleo, dengan deita dan kemarahannya. Medan: Waspada.

Setyohadi, B. (2007). Tipologi pola spasial dan segregasi sosial lingkungan Permukiman Candi Baru. Jurnal Tekhnik Sipil \& Perencanaan, 2(9), 97-106.
Sigit, G. (2015). Ruang Netral di Kota Ambon: Segregasi dan Integrasi Ruang Kota. In Urban Studies and Development (pp. 30-42).

Sinulingga, B. D. (1976). Pembangunan Kota: Tinjauan Regional dan Lokal. Jakarta: Pustaka Sinar Harapan.

Skinner., W. G. (1963). The Chinese Minority. In R. McVey (Ed.), Indonesia (pp. 115-126). New Haven: HRAF.

Small, J. R. W. (1968). The Military Politics of North Sumatera: December 1956-October 1957. Indonesia.

Smith, A. D. (1981). Chosen People: Why Ethnic Group Survive? Ethnic and Racial Studies, 2(2).

Sukanti, S. C. (1979). Kota di Dunia Ketiga. Jakarta: Barata Karya Aksara.

Sullivan, J. L. (1982). Political Tolerance and American Democracy. Chicago: University of Chicago Press.

Sullivan, J. L. (1999). The Psychological Underpinnings of Democracy: A Selective Review of Research on Political Tolerance, Interpersonal Trust, and Social Capital. Annual Review of Psychology, 50, 625-650.

Susanto, E. (2018). 10 Kota Paling Toleran di Indonesia, Jakarta Tidak Masuk. Retrieved April 29, 2019, from https://nasional.tempo.co/read/1153380/10-kotapaling-toleran-di-indonesia-jakarta-tidak-masuk

Tjiptoherianto., P. (1999). Urbanisasi dan Pengembangan Kota di Indonesia. Populasi, 9(2), 57-72.

UNESCO. (2004). Tolerance: the threshold of peace $A$ teaching/learning guide for education for peace, human rights, and democracy. France: UNESCO.

Veer, A. van der. (2013). The Pao An Tui in Medan: A Chinese Security Force in Dutch Occupied Indonesia, 1945-1948. Utrecht University.

Vermeer, T. (2012). The influence of religion on social tolerance in East-and West-Europe: A multi-level analysis. Tilburg University.

Wertheim., W. F. (1965). The Trading Minorities in Southeast Asia. In East-West Parallels: A Sociological Approach. The Hague: Van Hoeve.

Zanakis, S. (2016). Global social tolerance index and multi-method country rankings sensitivity. Journal of International Business Studies., 47(5), 480-495. https://doi.org/10.1057/jibs.2016.5 